\title{
CENTRAL ASIA AND CHINA RELATIONS: IMPLICATIONS TO INDIA
}

\author{
By P.Stobdan (India)
}

China has come a long way in the perspicaciously translating the political challenges emanating from Central Asia, in the face of the Soviet implosion, into one of economic opportunities. In fact, until the 9/11-episode, China scored consecutive diplomatic successes unparallel compared to other international actors in the region. Beijing's initial apprehension ranged from ideological isolation to cope up with transnational ethnic resurgence. China was cautious with the events unfolding in Central Asia, describing them as "internal affairs". Chinese were, in fact, perturbed and took defensive postures, adopting even strident tone to forestall any adverse effect on China. Chinese Vice-President, Wang Zhen's instruction in August 1991 to PLA troops in Xinjiang to "form a steel wall to safeguard socialism and the unification of the motherland" was seen in response to the Soviet collapse. ${ }^{1}$

\section{China's strategic perceptions of Central Asia}

However, as the dust of Soviet collapse settled down, China saw Central Asian new political environment changing in its favor. Chinese experts were quick to assess the evolving trends and argued that there is no need for "excessive reactions" since Central Asia Was unlikely to see the situation faced by the Baltic States. ${ }^{2}$ Moreover, China realized that its security environment has rather improved and instead made strategic gains on a number of fronts:

A formidable super-power and its principal military and ideological competitor, which since mid-1960s had tried to encircle China and undermined China's periphery in conjunction with Vietnam, Mongolia, India and Afghanistan, has disappeared.

- Russia's preoccupation with the West compounded by internal political an economic crises significantly diminished Chinese threat perception of Russia.

${ }^{1}$ P.Stobdan, "China's Central Asia Dilemma", Strategic analyses, Vol.XXII No. 3, June, 1998. Also see John W.Garver, "The Chinese Communist Party and Collapse of Soviet Union", The China Quarterly-133, March 1993, pp. 96-110.

${ }^{2}$ Based on discussion author had at the Beijing Institute for Strategic Studies (BIIS), China Institute of Contemporary International Relations (CICIR) and other important Chinese institutions in China in 1992. 
- Reduction in Russia's armed forces, the strategic nuclear weapons and the Pacific fleet by 40 per cent, as well as Kazakhstan's commitment to eliminate nuclear weapon on its soil has titled the military balance in China's favor. $^{3}$

- Smaller national armies completely asymmetrical to China's deployment in Xinjiang replaced the Soviet military in Central Asia. The Central Military Commission (CMC) annual report in 1991 did not mention Central Asian Republics as direct challenge to China's national security. ${ }^{3}$

As the initial euphoria died down, China took a sanguine view about the threat of Islamic fundamentalism. Beijing, in fact, was pleased to see central Asian governments themselves standing up against the rising Islamic opposition. Central Asian armies soon got engaged in fighting fundamentalist forces. Moreover, Beijing quickly turned to its old Islamic friends, including the Talibans to spare China from fundamentalist drive in exchange of clandestine nuclear and missile programmes. China took Iranian President, Rafsanjani to Urumchi, the capital of XIANJIANG in 1992.

It was against this backdrop China approached Central Asian states and established diplomatic relations with them in accordance with its "Five Principles of Peaceful Coexistence" while obtaining Central Asian endorsement of China control over Xinjiang and Taiwan. Between 1992-1993, the new states signed all necessary bilateral agreements for cooperation with China.

As the Soviet built economic infrastructure began to disarray, Chinese were quick to reaped advantage in the region's economic sector. Central Asian leaders were unable to ignore China's economic achievements while China added the metaphor "Revival of the Silk Road" to its open door policy for bolstering its interest in the region. The Silk Road did fulfill Central Asian immediate commercial needs, reminding them as also about the prosperity and thriving Central Asian culture of the past. The concept of Silk Road as the ancient continental bridge did help China remove key political and cultural barriers. China capitalized on the concept and implemented a number of ambitious projects including the construction of transnational railways and highways, enabling it to bring huge trade and investment in the region. ${ }^{4}$ In

${ }^{3}$ Guocang Huan, "The New Relationship with the former Soviet Union," Current History, September 1992, p.254. The New Russian President, Yeltsin,s pronouncements were viewed by Chinese Leaders not only as anti-Communists but also as hostile to the leadership in Beijing. At several occasion, Chinese humiliated Yeltsin and supported Gorbachev with regards to changes in the former Soviet Union. In 1989, Chinese Communist Party General Secretary, Jiang Zemin refused to meet Yeltsin in Moscow.

${ }^{4}$ Ross H.Monro, “China's Waxing Spheres of Influence” Orbis, Fall 1994, pp. 590-605. 
April 1994, Chinese Premier Li Peng's triumphal tour to the region gave a new impetus by proposing a pipeline along the Silk Road. ${ }^{5}$

China treated carefully in Central Asia, so as not to arouse Russia's suspicion. Beijing avoided direct political confrontation and enhanced only economic leverages. Once the Russians decided to sell their advanced weapon system to China, Beijing also went ahead to bolster ties with Central Asian states in technical and military fields, building direct and indirect linkages with Central Asian key military firms. Even in the "Great Game" of pipeline politics, China stepped in only in 1997 after the Americans entered the region.

Although, there are several dimensions of Central Asia - China relations, I will limit myself to discussing only issues relating the Shanghai Five, the linchpin of China's strategy in Central Asia. While the Central Asian states offer vast economic opportunities-a hub for energy distribution and new regional cooperation schemes, the region is still rife with enormous threats to China. This paper intends to explore the nuances attached to Central Asia-China relations, specifically, the nature and current status of Shanghai Five, now called as the Shanghai Cooperation Organization (SCO). I would argue in the paper that despite the laud projection of the SCO as a viable regional grouping, China would fail to attain the leadership role in Central Asia.

\section{The Shanghai Five}

The Shanghai Five came as a product of post-Cold War development in Eurasia. Several key factors underpinned its evolution. Firstly, it was borne out of China's rising insecurity along its frontiers, especially the pending territorial disputes having potential of invoking strong nationalistic resurgence. The domestic political stability was a concern for the Central Asian states too. They found commonality of interest with China in fighting against religious extremism, although China held different view on the Alghan imbroglio. For China, the international isolation in the wake of the Tianamen Incident and the rising military tension in the Taiwan Strait was a matter of serious concern. When the West started to project China as a potential threat to Asian security, Beijing looked for support to build a multi-polar world as against US proclaimed "new world order".

The Shanghai Five came about in the backdrop of Russia's declining international status. Russia was grappled with the period of serious domestic political upheaval and economic hardship. The Western pressure on Russian

${ }^{5}$ See summary of World Broadcasts, SWB/FE/1978 G/1 April 22,1994. 
Human Rights records, especially on the Chechnya question and NATO's eastward enlargement posed serious challenges to Russia's security, and hence became compelling factor for Russia to engage the Chinese. ${ }^{6}$ The Central Asian states too could not take risk on their external front, especially when the political authorities faced mounting domestic challenges from diverse ethnic and religious elements. The soviet strategic withdrawal had left Central Asian states with feeble armies incapable of defending large borders with China. Moreover, the need for them to gain international legitimacy and diversify from Russian control was uppermost national priority. The declining Russia-India nexus even in the economic and commercial spheres helped widen Central Asia corridor for Chinese economic penetration. The prolonged Afghan conflict only hindered Central Asia states to look for outside support other than China. Moreover, the inter-state rivalries arising out of dispute over land and water had made some Central Asian states to look towards China. Therefore, the Shanghai Initiative came in the face of international disorder-desperate groups trying to overcome their inherent national weaknesses.

As China started to set the agendas, the commentators described the Shanghai phenomenon to China applying old imperialistic methods- i.e., "divide and rule" with new realities. ${ }^{7}$ The group was formed in 1996, ostensibly to provide a platform for addressing the joint border issues. ${ }^{8}$ From the outset, China tried to deal individually with Central Asian states and resolve the problems bilaterally as against Russian and Central Asian insistence to represent as a "joint delegation". Following the Summit, China, however, managed in July 1996 to sign an agreement bilaterally with Kyrgyzstan to resolve the border issue.

The Second Summit held in Moscow in April 1997 had focused only on disarmament and reduction of forces along the borders. It was the time when the Russian forces were already making speedy withdrawal and the Central Asian attentions were increasingly getting diverted to fight Islamic oppositions. The Third Summit held in July 1998 focused on non-military issues that concerned China. Among others, the joint declaration stressed for respecting national sovereignty and territorial integrity, fight against separatists and religious extremists. China also pushed the economic agenda. It was also on

${ }^{6}$ Boris Yeltsin during his visit to China in December 1999 warned by saying "he, (Clinton) must have forgotten for a moment what Russia is. It has a full arsenal of nuclear weapons". While responding to Clinton's tough remarks on Chechnya, Yeltsin said "everything will be as I agreed with Chinese President, Jiang Zemin and we will dictate how to live'. Reuters, Moscow, December 9, 1999

${ }^{7}$ Richard Walsh. J.,"China and the New Geopolitics of Central Asia”, Asian Survey, Vol.XXXIII, No. 3, March 1993.

${ }^{8}$ Commentary "The agreement that holds the world's attention", April 27, 1996. 
occasion for China to provoke Central Asian states to harshly condemn the nuclear tests in South Asia. By this time, China managed to divide the $3+1$ joint delegation into separate individual member states and declared the forum a truly multi lateral. This time China concluded a separate treaty with Kazakhstan on the basis of one signed in 1994 to resolve the territorial disputes along Xinjiang frontiers.

The Fourth Summit held in Bishkek in August 1999 was a mere declarative. The document reaffirmed their commitment for non-interference and not to allow their territories to be used against others interests. China then quickly singed a supplementary agreement with Kyrgyzstan to resolve the border issue.

The Fifth Summit was postponed several times amidst uncertainty over how the post-Yeltsin Russia would view relationship with China. The Summit was finally held in Dushanbe in July 2000 with Uzbekistan joining as an observer. The meeting was crucial as it promised to redefine the contours of future RussiaChina relations. The tentativeness was over when Putin decided to continue with Yeltsin, policy for a strategic alliance with China. However, unlike Yeltsin, who took a soft-pedaling on Central Asia, Putin came to Shanghai meeting after doing some homework. Putin first took measures to strengthen the CIS, engaged Uzbekistan in a military relationship, worked with Kyrkyzstan to tighten its borders with Tajikstan, decided to establish a regional joint terrorism center and participated in Southern Shield 2000 military exercises. Moscow's increased regional involvement, coupled with Uzbekistan's inclusion in the group raised the hope Shanghai Five becoming a strong organization that would involve in joint operation against Islamic Militants. But the meeting ended up with decision, which were general, declarative and non-committal in nature. The anchors of the grouping only used the occasion to make "anti-West" and more precisely "anti-US" rhetoric in the wake of US decision to cancel the 1972 ABM treaty and called it "Shanghai Forum". Yet again, China signed a separate agreement, this time with Tajikistan to settle the border issue permanently.

The Sixth summit held in Shanghai in June 2001 welcomed Uzbekistan as a full member, and even discussed about expanding the membership to bring in South Asian countries. Pakistan had already expressed willingness to join it earlier. Interestingly, Russia and Central Asian states insisted that the organization become Shanghai Cooperation organization (SCO). China first opposed the transformation but agreed for the change only after the election of Bush as the US President. ${ }^{9}$

\footnotetext{
9 "Russia has Misgiving about Shanghai Cooperation Organization", Eurasia Net, June 20. 2001
} 
The sixth summit took place amidst heightened concern about Central Asian security, as regional countries, especially Kyrgyzstan and Uzbekistan battle to contain mounting pressure from Islamic insurgents. While the western media described the SCO as an "anti-separatist club", Putin said they were against a basket of evils: religious extremism, terrorism, organized crime and drug trafficking. Putin noted that "Russia's withdrawal from Central Asian region after the Soviet disintegration created a power vacuum, and religious extremism and terrorist organizations began filling the vacuum. "But once again Russian and Chinese distaste for TMD overshadowed their genuine concern of radical Islam. Though, the members graciously welcomed President Karimov of Uzbekistan, the officials both in Moscow and in other capitals of Central Asian states showed misgivings about Uzbekistan's entry. They, particularly, saw the risk of Tashkent complicating rather than resolving Central Asian security problem. The dilemma created by Uzbekistan after it pulled out from the Collective Security Treaty (CST) in 1998 was fresh in their mind. But Uzbekistan had to join the SCO as result of rising threat from the IMU that made series of incursions through two summers. By this time the SCO became a unique cocktail each members pursuing different aims. The only converging point of interest was containing of Islamic fundamentalism. Problems in Chechnya, Xinjiang, Batken, Osh, Farghana etc., became good reference point. It was then the SCO started attracting new Delhi's attention too for a membership. But this was a scenario prior to the $9 / 11$ incidents. In fact, interest for membership showed by India, Iran and Mongolia only helped boost the SCO's credibility.

\section{Post September 11 and the SCO}

In the aftermath of 9/11, the SCO's relevance and viability became a matter of increasing debate. The Seventh Summit, which met in St. Petersburg in June 2002, desperately searched for a unifying operational framework. The meeting approved a 26-point charter to base the SCO secretariat in Beijing and to establish an anti-terrorism center in Bishkek. The joint declaration stressed that global order should be based on "mechanisms of collective decision-making and democratization of international relations." 10 The focus now appeared to have shifted from fighting Islamic fundamentalism to that of dealing with the US presence in Central Asia. The St. Petersburg meeting clearly witnessed broad difference among the members concerning the strategic priorities of the organization. The 9/11 terrorists attack and their aftermath completely exposed the

\footnotetext{
${ }^{10}$ Sergei Blagov, "SCO Continues to Search Operational Framework", Eurasia Net, June 11, 2002
} 
SCO's earlier commitment to stand against growing US unilateralism. One after another member states led Uzbekistan offered military bases to the US. There were no multilaterial consultations among SCO members prior to the arrival of US troops in Central Asia, except that Putin had telephonic conversation with the leaders of Central Asian states. Moreover, the tone in St. Petersburg had changed as the declaration favored a move towards "new and stable Afghanistan, free from terror, war, drugs and poverty" Russian Foreign Minister suggested member states to cooperate with the US in promoting stability in Afghanistan. The organization that earlier routinely attacked the US has now started reverting to developing interstate trade component. Nevertheless, China tried to revive the original spirit and sought to make SCO the region's authoritative voice. Chinese Foreign, Minister Tang Jianxuan promised to reporters in Moscow in June 2002 that SCO would achieve international significance. He noted that the SCO is not " a club for empty discussions, but a viable institution capable to make an important contribution to the international war on terror." Beijing was also keen that other regional bodies in Central Asia do not grow at the expense of the SCO. China has been taking somewhat restrained interest in the CICA process initiated by Kazakhstan. Jian Zemin decided to attain the Almaty Summit in June 2002 only after Prime Minister Vajpayee confirmed his participation.

Undoubtedly, the US led war against terrorism has completely demolished the relevance of SCO. The Chinese driven organization got discredited in the face of 9/11 episodes as the member states instead turned to Washington to fight against fundamentalism. In fact, the 9/11 fully exposed the China's duplicity of fighting terrorism at home while maintaining full Liaison with the Taliban and Pakistan, which long sustained terrorism as their state policy. Beijing preached the SCO members to resists fundamentalism, but when came to real action, it chose to abstain from the UN sanction against the Taliban. While responding to 9/11, China sought complete evidence from the US that Al-Qaida had indeed launched the attacks. This was an enough message that China cannot be a serious partner in war against terror.

Notwithstanding the euphoria associated with its achievements, there are little signs the SCO becoming a counterweight to the US hegemony. Though, the organization boasts about adhering to pragmatic and incremental approach to multilaterial problems, most delicate issues were resolved bilaterally. Central Asian states too owing to inter-state rivalry adopted bilateral rather than 
multilaterial channels. The Sino-Russian bilateral affairs, including the weapon transactions overshadows the scope of the SCO.

It is being strongly argued that Central Asian states reached border delimitation and also water sharing agreements with China without ever consulting Moscow. The border issue, particularly Kyrgyzstan's ceding to China about 125.000 hectares of territory has recently led to large-scale public violence, resulting into killing of a Chinese diplomat in Bishkek. The border issue has now become emotional and continues to remain the cause for internal instability there. This may also happen in Kazakhstan eventually, were the authority is being accused of ceding large chunk of territory to China.

There are also little hopes that the SCO could cooperate in economic affairs in a major way. The smaller SCO members like Kyrgyzstan fears that its resources such as minerals, fuel and water will become vulnerable to exploitation by bigger members. Water is already a critical political issue in Central Asia. Some states are using water as a political tool. Not just grubbing of land, China is being accused of diverting Central Asian major river waters for the development of Western China. The Emel River that flowed into Kazakhstan has already dried up. China is said to be using "divisive" tactic even on the Black Irtysh issue between China-Kazakhstan and Russia.

The differing strategic perceptions among the member states also seriously hinder the SCO's growth. Uzbekistan's complete alignment with the US after the $9 / 11$ has dampened the organization's spirit. Others are viewing Uzbekistan as a fickle member as Tashkent started to skip the SCO sessions. Even before the 9/11, Karimov had indicated that the SCO should largely remain a forum for debate on global political issues. Uzbekistan is likely to continue with its unilaterial approach in confronting Islamic radicalism. Tashkent's independent action in the past to the ward the IMU has fueled inter-state tensions. Notably, the decision to time its frontiers with Kyrgyzstan and Tajikistan caused considerable distrust and animosity between them. Such rivalries even mired CIS effort at countering Islamic resurgence. The SCO has shown neither the inclination nor capabilities to resolve these disputes.

\section{Russia's Renewed Interest in Central Asia}

There are little doubts that Putin's ascendancy since 2000 has further diluted the importance of the SCO. Russia, under Putin, has been increasingly pushing both military and economic as key leverages to promote its interest in Central Asia. In the last two years, Russia has mutely regained control over Central Asian key sectors including oil, space, minerals, defense industry. More- 
over, Moscow has made incisive policy response-insinuating US entry in Central Asia enhancing rather than threatening Russian national interests. The gains on security apart, Russian perceive US engagement, especially in the energy sector, would bring dividend in the longer run, so long as Russia controls the supply routes. Central Asians themselves have reaped enormous benefits by cooperating with the US in its war on terror. Not just the US aid to them has doubled; military cooperation begets resourses to revitalize Central Asian key military segments. In this context, Russian's now see situation in its "near abroad" changed fundamentally. Russians do not seemingly see disputes with West vanishing completely, but the nature of differences and Western compliance to concede Russia's viewpoints have altered conciderably. ${ }^{11}$ Russia now finds more reasons to return to Central Asia. Putin is skillfully using the American rhetoric with its emphasis on the anti-terrorism campaign and right of preemptive action. The opening of new Russia military base at Kant airport in Kyrgyzstan on 5 Desember underscores Moscow's intension to remain as dominant regional power in Central Asia. Putin termed it as achieving "a new quality" to regional security arrangements, while Central Asian are beginning to see "no alternative" to Russian support. Besides the air unit, Russian troops will form part of rapid-deployment force to be stationed in Kyrgyzstan under the CST. Putin himself said in November 2002 to Ekho Moscvy Radio, "that the era of Russian political concessions-which began with 1991 and continued through the postSeptember 11 appearance of US military bases in Central Asia - was coming to an end".

While Russia and Central Asian states are likely to continue engagement with China through the SCO, their decision to take the CIS and CST more seriously than before would significantly undermine the SCO's relevance. As the CST observed its $10^{\text {th }}$ anniversary last year, efforts were made to redefine its relevance. The CST was transformed into Collective Security Treaty Organization (CSTO) last year with new charter and Russia as dominant player. The organization conducted a series of large-scale military maneuvers in the southern belt of Central Asia and in the Caspian Sea. Not surprising that the SCO's anti-terrorism center based in Bashkek will have very limited role to play in the Central Asian security affairs-collecting information on drug trafficking and checking trans - border criminal activities.

Washington's muted response to Russia's December 5 announcement indicated that the US no longer views the Russian military deployment in Central

${ }^{11}$ Russian Foreign Minister, Igor Ivanov's statement on Russian's foreign policy concept, spelled out in November 2002 prior to NATO's Summit in Prague, Kommersant Daily, Moscow, November 2002. 
Asia as a zero-sum game. The experts opine that Moscow and Washington are emerging as a twined alternative to Chinese hegemony in Central Asia. The Russian troops could now complement American troops in Bishkek to collectively fight the stateless foes such as Al-Quida. Putin is doing what Yeltsin could not do. The essence of China's strategy so far, as also those of Central Asian states was to play on the contradiction between Russia and the West. This has begun to change now. As Russia's economy has starting to look up, Moscow, obviously, is going to implement policies to safeguard its interest.

Central Asian states are recognizing the fact that Russia has gained more leadership role after the 9/11. President Karimov also acknowledged last year by saying that "present-day Russia is not the Russia of the 1990s."

\section{Fear About China}

Notwithstanding the public posturing about close Sino-Russian relations, apprehensions about growing Chinese influence in the region run deep in most Russian and Central Asian minds. Outside the governments, debate continues weather China is an ally or a competitor. The Central Asian have historical reasons to be worry about China. The Chinese word Xi Yu remains a historical title for China's Western Provinces that includes much of Central Asia. ${ }^{12}$ Chinese Ambassador to Kazakhstan reminded this to them in 1992. The Kazakhs still have saying "when a black Chinese comes, a yellow Russian would seem appear father." Central Asians are keen to cooperate in the new realities but wish to be vigilant about China's long- term goals. They fully suspect that China is in search of lebensraum. Already, the ethnic Chinese are making forays in most industrial towns in Kyrgyzstan and Kazakhstan. The Western Kazakh city like Aktybinsk has already become a China town. Besides, Chinese have been encouraging the ethnic Uighurs and Kazakhs migration from Xinjiang to Kazakhstan. The seriousness of this problem was realized in the recent years, as the Kazakh authorities decided to shift the capital of Almaty Oblast to Taldykorgan, closer to China's border, in order to offset the imbalance being created by Chinese migration.

There appears to be a limit to what Central Asian could do to prevent the Uighur movement getting more momentum. In Kazakhstan, several Uighur

\footnotetext{
${ }^{12}$ China had a territorial dispute with Russia since late seventeenth century. During the period of rift between China and the Soviet Union, Chinese maps showed parts of Kyrgyzstan, Tajikistan and Kazakhstan as far as Lake Balkhash, as well as the Pamirs, within the borders of China. China claimed that Tsarist Russia had annexed thousands of square miles from China in 1880s. See Michael Freeberne, Essays in Political Geography, 1965 , p.203.
} 
separatist outfits are now operating legally. ${ }^{13}$ Kazakhstan and Kyrgyzstan are home for a large Uighur Diaspora. Many of these outfits, including the United National Revolutionary Front of Eastern Turkistan (UNRFET), led by Yusupbek Mukhlisi, have become more vocal in the recent months. Kazakhstan's over 200.000 Uighur population is becoming more prosperous and assertive. The Uighur activities are increasingly threatening to turn into an armed conflict involving China and Central Asian states. If not handled carefully, the Uighur issue may re-bounce on Central Asian states. Though, China has evidently gained in short term in its fight against fight Islamic extremists in Xinjiang, Western entry in the region with enhanced political interest will inexorably pose longterm difficulties for China. In fact, Uighurs living outside China beginning to foresee better times ahead. Beijing now tries to revive the SCO's spirit and regain leverages while (a) massing

Troops along Central Asian frontier; (b) providing military assistance to the states; (c) reviving interest in Central Asian oil. Recently, Beijing did gain success by resolving territorial disputes with Tajikistan in its favour.

\section{Implication to India}

From China's standpoint, the SCO provides perfect political and economic mechanism - containing destabilizing effects and obtaining economic benefits. For Russia, it is a forum that never discounts its interests in Central Asia. Russia also intends to use the forum only for an economic engagement with China. For Central Asians, the organization provided higher degree of independence by playing off Chinese and Russian influence against each other. Therefore, the SCO essentially provided a delicate equilibrium among the participants in the post-Cold geopolitical disorder. India has never featured in the equilibrium, even though Central Asians always perceived India's potential to be a countervailing factor in the region. This articulation finds pronouncement both within and outside governments. Central Asian view India conspicuously lacking framework or not being able to find itself a place in any of the concentric rings that outside actors have embossed for dealing with the region.

Central Asia forms a critical and paramount component in India's security calculus, both for containing unstable situation in and around Afghanistan and Pakistan, and against growing China's influence all around Asia. The West for long overlooked and discounted India's historic and strategic connections with Central Asia. The implications of SCO's dilution should open Central Asia's

13“Kazakhstan's Uighur separatists are "trump card” against Chinese claims" Karavan, Almaty, in Russian, November 29. 2002.p. 7. Also see BBC Mon CAU 301102 kr/qu. 
door for India. This strategic reversal means India and Russia gaining position to exploit the US-China contradictions.

New Delhi has been over-emphasizing the importance of the SCO, perhaps looking at it from a narrow perspective of combating terrorism. China's interests in the SCO extend beyond the resolution of its borders to bring the new states under its strategic fold. In fact, the trends indicate that China has been adopting a policy scheme of replicating its Pakistan policy in Central Asia. A careful analysis indicate China's conceptions moving along a multiple but interrelated lines of thought; (a) resolve its territorial problems with these states with best possible terms and conditions, (b) preclude any possible threat that may challenge its political control over Xinjiang, y recognition of region's importance and also of various individual states as countering other powers such as Russia, India and the US.

The SCO was originally meant to resolve the volatile border issues. India, having mechanisms to deal with China on border issues, does not required to be in the SCO. Central Asian experiences, in fact, show that China used various high-handed policies including intimidation, subversions, destabilization and allurement of individual, groups and states to settle its borders. Fore example, Kazakhstan resolved its borders in the backdrop of China's promise to make multi-billion investments in oil sector and a long-distance pipeline project for Kazakh oil export to East Asian market. By making the border resolution as a prerequisite to it, the dispute involving vast stretched of territory was finally resolved in China's favour. The issue still remains a contentious one as opposition parties; media and intelligentsia vehemently oppose Kazakh authority for compromising on the border issue. What has been described as the "deal of the Century" involving 3.4 billion dollars investments by China in Kazakhstan's oil sector, signed in 1997 remains a non-starter. A similar factics is being used by China on the river-water disputes. For example, on the Irtish river dispute, the Kazakhs had to make two concessions at the early stage of preparing a framework for negotiation. Astana has ceded some 500 square kilometers of territory to China and dropped its earlier insistence that Russia should also be a party to the negotiation. (The river flows from China via Kazakhstan into the Russian federation). By managing to solve problems with Central Asian states, China by wishes to single out India on the border issue.

On the issue of terrorism too, China cannot be taken as a reliable partner. In fact, China has been a part and not a solution to terrorism. In Central Asia, China though tended to avoid direct face-off with Russia, but adhered to other subversive means including Islamic militancy to the point of coercing individual 
Central Asian governments to come to terms with Beijing. It is quite clear that Chinese in connivance with Pakistanis and the Taliban fomented Islamic insurgencies, creating hotspots such as Batken in 1999 and 2000, which compelled Kyrgyzstan to seek assistance from China. Consequently, China responded through both military and economic aids while inducing the former to resolve difficult border problems on China's term. The Kyrgyz government is now confronting wide public criticism for signing a secret agreement, surrendering some large territory to China in 1999. Kyrgyzstan received substantial military aid, as well as deepened its military contacts with China during the year 2000 .

Similarly, Uzbekistan's compulsion to join Chinese led organization came as a direct response to heightening threat posed by fundamentalist groups like IMU led by Juma Namangani and Tohir Yuldash. The IMU was supported by the Taliban and in turn by China's ally Pakistan. China, under no circumstances, is expected to use military force against countries where terrorists are bred. Nor, the Sino-Pak nexus is going to change by India joining the SCO. Instead, the SCO will become another forum for Pakistan to mislead the Central Asians on Kashmir.

In the absence of a direct land border with Central Asia, India's ability to assert in the SCO will be rather meager. The Forum has been used to voiced rhetoric against the West, something, which New Delhi could wish to avoid. Most Importantly, the SCO is a group - composing of communists, autocrats and semi-democrats, who have little respect for human rights, respect for ethnic groups and religions. India certainly cannot effort to confuse Turkic nationalism of Uighur people with Islamic fundamentalism.

India's policy outlook demands broadening the conceptual parameters of Central Asia to include wider Eurasian space. Major powers are broadening their perspectives, as dynamics evolving in Kazakhstan and Kyrgyzstan are increasingly becoming China centric. This is not to suggest India should not cooperate with China and Central Asian states. It would be imprudent though for India joining the SCO, a regional framework involving India, China and Central Asian states minus Turkmenistan could form a viable option for a longterm cooperation. Several transportation highways, railway lines and pipelines across the Tian Shan and Pamirs are creating new area of regional cooperation. Beijing has already prioritized development of Western China in its third phase of economic reforms. A web of energy pipelines including from Tarim to coastal China is going to change the regional economic landscape lying north of India. 
As it is, the Afghan-Pakistan route is not available and the much talked about cooperation through Iran has borne little success, it is time that we factor China in our Central Asia policy. Above and beyond, India has been a legitimate player in Central Asia until not so long ago. In the changed circumstances, India must stake benefit from China's development plans in Xinjiang and Tibet. The feasibility of constructing oil/gas pipeline from Central Asia along Western China connecting to Northern India is now well established. Should this happen, it would bring about unprecedented strategic change, let alone endowing energy supplies to entire Northern India. 